\title{
Streptococcus minor sp. nov., from faecal samples and tonsils of domestic animals
}

\author{
M. Vancanneyt, ${ }^{1}$ L. A. Devriese, ${ }^{2}$ E. M. De Graef, ${ }^{2}$ M. Baele, ${ }^{2}$ K. Lefebvre, ${ }^{1}$ \\ C. Snauwaert, ${ }^{1}$ P. Vandamme, ${ }^{3}$ J. Swings ${ }^{1,3}$ and F. Haesebrouck ${ }^{2}$ \\ ${ }^{1,3}$ BCCM/LMG Bacteria Collection ${ }^{1}$ and Laboratory of Microbiology ${ }^{3}$, Faculty of Sciences, \\ Ghent University, Ledeganckstraat 35, B 9000 Ghent, Belgium \\ ${ }^{2}$ Laboratory of Veterinary Bacteriology and Mycology, Ghent University, Salisburylaan 133, \\ B 9820 Merelbeke, Belgium
}

\begin{abstract}
Nine isolates, which were obtained from tonsils, anal swabs and faeces of dogs and from tonsils of a cat and a calf, constituted a homogeneous but unidentified taxon after screening with tRNA intergenic length polymorphism analysis and whole-cell protein fingerprinting. 16S rDNA sequence analysis classified representative strains in the genus Streptococcus. Highest sequence similarity (95.9\%) was obtained with Streptococcus ovis. Growth characteristics, biochemical features, DNA-DNA hybridization and DNA G +C contents of selected strains demonstrated that they represent a single, novel streptococcal species. The name Streptococcus minor sp. nov. is proposed for the novel species; the type strain $\left(O N 59^{\top}=L M G 21734^{\top}=\right.$ CCUG $\left.47487^{\top}\right)$ was isolated from a dog tonsil.
\end{abstract}

Identification techniques that are linked to extensive databases are helpful to discern novel groups of bacteria. For lactic acid bacteria (LAB), tRNA intergenic length polymorphism analysis (tDNA-PCR) and SDS-PAGE analysis of whole-cell proteins have been used intensively as routine identification systems; both approaches are linked to databases that comprise all or nearly all LAB species with validly published names (Pot et al., 1994; Baele et al., 2000, 2001, 2002).

In an ongoing study of LAB diversity in faecal samples and tonsils of dogs, tDNA-PCR was performed as described previously (Baele et al., 2000). Strains were cultivated on Columbia horse blood CAN agar (Oxoid) in a $\mathrm{CO}_{2}$-enriched atmosphere. Genomic DNA was extracted as described by Baele et al. (2000). tDNA-PCR was performed by using the consensus primers T5A (5'-AGTCCGGTGCTCTAACCAACTGAG-3') and fluorescently labelled T3B (5'-AGGTCGCGGGTTCGAATCC- $3^{\prime}$ ), which were developed by Welsh \& McClelland (1992) and are directed against the conserved edges of the tRNA genes. PCR mixtures and cycle

Published online ahead of print on 26 September 2003 as DOI 10.1099/ijs.0.02818-0.

Abbreviations: $L A B$, lactic acid bacteria; $t D N A-P C R$, tRNA intergenic length polymorphism analysis.

The GenBank/EMBL/DDBJ accession numbers for the 16S rRNA gene sequences of strains LMG $21734^{\top}$ and LMG 21735 are AY232832 and AY232833, respectively.

A figure showing an extended phylogenetic tree is available as supplementary material in IJSEM Online. conditions were the same as described previously (Baele et al., 2000). Capillary electrophoresis of DNA fragments was done by using an ABI Prism 310 Genetic Analyser (Applied Biosystems). Electrophoretograms, which were obtained with GENESCAN software, were compared with those in the database by using in-house software. A separate cluster of seven strains with similar tDNA-PCR fingerprint patterns was delineated. tDNA spacer fragment lengths for strains in this cluster were $62 \cdot 5,65 \cdot 4,66 \cdot 3,85 \cdot 8,86 \cdot 8,155 \cdot 9$, $252 \cdot 6,257 \cdot 5,258 \cdot 8$ and $341 \cdot 7 \mathrm{bp}$; these fragments allowed the strains to be distinguished from other known LAB species that were included in the database of the Department of Bacteriology, Faculty of Veterinary Medicine (Baele et al., 2000, 2001, 2002). The seven strains were isolated on different occasions from seven dogs, all of which belonged to different owners who lived in different locations in Belgium. Two strains, LMG $21734^{\mathrm{T}}\left(\mathrm{ON} 59^{\mathrm{T}}\right)$ and LMG 21735 (ON72), were obtained in 1991 from tonsils; two, LMG 21729 (ON55) and LMG 21733 (ON119), were obtained in 1991 from intestinal contents at necropsy; and three, LMG 21730 (eve 16c), LMG 21731 (eve 113) and LMG 21732 (eve 7a), were obtained in 2000 from anal swabs of individually kept healthy dogs.

All seven dog isolates were investigated further by using PAGE of whole-cell proteins. Strains were cultivated on Columbia agar base (BBL) that was supplemented with $5 \%$ horse blood for $24 \mathrm{~h}$ at $37^{\circ} \mathrm{C}$ under microaerobic conditions. Whole-cell protein extracts were prepared and SDSPAGE was performed as described by Pot et al. (1994). Densitometric analysis, normalization and interpolation of protein profiles and numerical analysis were performed by 


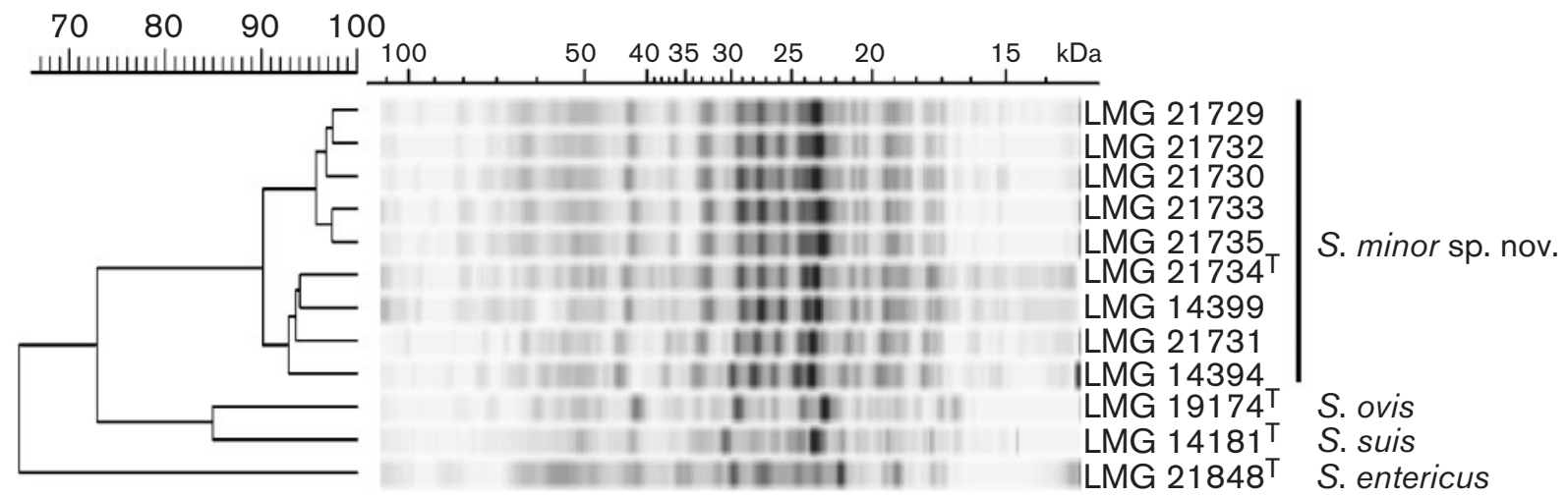

Fig. 1. Protein profiles and corresponding dendrogram, derived from UPGMA linkage of correlation coefficients ( $r$, expressed as a percentage value for convenience) of $S$. minor strains and some related reference species.

using the Gelcompar software package, versions 3.1 and 4.0, respectively (Applied Maths). Whole-cell protein profiles of the dog isolates were initially compared with patterns that represented all currently described LAB species; this confirmed that the strains are a homogeneous taxon that occupies a separate position (Pot \& Janssens, 1993; data not shown). Furthermore, comparison with thousands of reference strains and field isolates showed that the dog isolates are nearly identical to two unidentified strains from other hosts, LMG 14394 (Ton 168) and LMG 14399 (Ton 10a), which were isolated in 1991 from the tonsils of a cat and a calf, respectively. Fig. 1 shows a dendrogram that was obtained after UPGMA linkage cluster analysis of all nine strains and related reference strains (see below).

The phylogenetic position of two representative strains, LMG $21734^{\mathrm{T}}$ and LMG 21735 , was determined by $16 \mathrm{~S}$ rRNA gene sequence analysis. DNA was extracted as indicated for tDNA-PCR. To amplify the $16 \mathrm{~S}$ rRNA gene, a PCR was performed by using the conserved primers $\alpha \beta$-NOT $\left(5^{\prime}-\right.$ TCAAACTAGGACCGAGTC- $\left.3^{\prime}\right)$ and $\omega_{\mathrm{MB}}$ ( $5^{\prime}$-TACCTTGTTACTTCACCCCA-3') and Taq Mastermix (Qiagen). After PCR products were purified by using a QIAquick PCR purification kit (Qiagen), sequencing reactions were performed by using a BigDye Terminator sequencing kit (Applied Biosystems) and primers ${ }^{\star} \mathrm{Gamma},{ }^{\star} \mathrm{O}, \mathrm{PD}$ and 3 , as described by Coenye et al. (1999). Sequences were determined by using an ABI PRISM 310 Genetic Analyser (Applied Biosystems). Phylogenetic analysis was done by using the GENEBASE program (Applied Maths). Pairwise alignment homologies were calculated and a dendrogram was constructed by using the neighbour-joining method. These data revealed that the strains belong phylogenetically to the genus Streptococcus (Fig. 2). Highest sequence similarities were obtained with Streptococcus ovis $(95 \cdot 9 \%)$, Streptococcus gallinaceus $(95 \cdot 5 \%)$, Streptococcus iniae $(95 \cdot 4 \%)$, Streptococcus entericus $(95 \cdot 0 \%)$ and Streptococcus suis $(94 \cdot 1 \%)$; these values are too low to consider a possible relationship at the species level (Stackebrandt \& Goebel, 1994).
DNA G $+C$ contents were determined for two dog strains (LMG $21734^{\mathrm{T}}$ and LMG 21735), the cat strain (LMG 14394) and the calf strain (LMG 14399). Strains were cultivated in brain heart infusion broth (Oxoid) for $24 \mathrm{~h}$ at $37^{\circ} \mathrm{C}$ under microaerobic conditions. DNA was extracted from $0 \cdot 75-1 \cdot 25 \mathrm{~g}$ cells (wet wt) by using the protocol described by Pitcher et al. (1989) with the following modifications: the washed cell pellet was resuspended and lysed in a buffer (10 mM Tris/HCl, $100 \mathrm{mM}$ EDTA, $\mathrm{pH} 8 \cdot 0$ ) that contained RNase $\left(200 \mu \mathrm{g} \mathrm{ml}^{-1}\right.$; Sigma), mutanolysin $\left(100 \mathrm{U} \mathrm{ml}^{-1}\right.$; Sigma) and lysozyme $\left(25 \mathrm{mg} \mathrm{ml}^{-1}\right.$; SERVA) for $1 \mathrm{~h}$ at $37^{\circ} \mathrm{C}$. Before addition of the GES (guanidium thiocyanate/ EDTA/Sarkosyl $)$ reagent, proteinase $\mathrm{K}\left(200 \mu \mathrm{g} \mathrm{ml}^{-1}\right.$; Merck) was added to the mixture for $15 \mathrm{~min}$. For determination of DNA G+C content, DNA was degraded enzymically into nucleosides as described by Mesbah et al. (1989). The nucleoside mixture was then separated by HPLC using a Waters SymmetryShield C8 column,

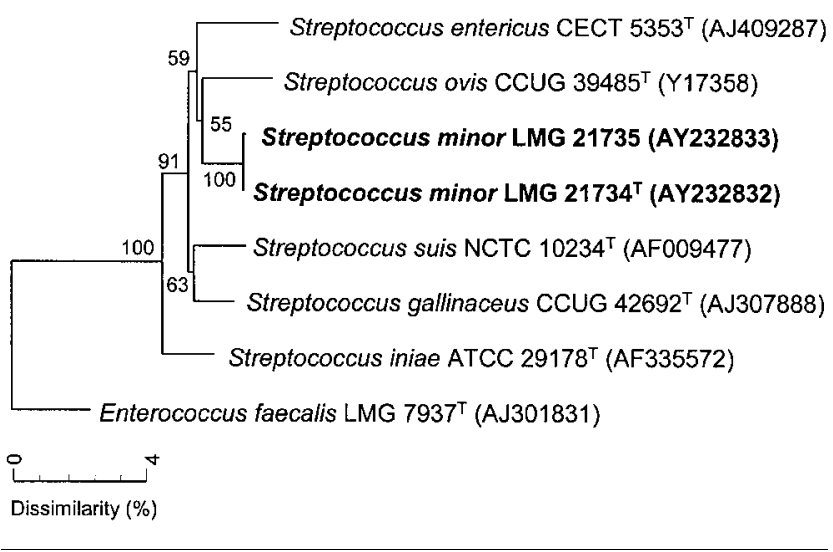

Fig. 2. Distance matrix tree showing the phylogenetic relationships of $S$. minor and other streptococcal reference species, based on 16S rDNA sequence comparisons. Enterococcus faecalis was used as the outgroup and bootstrap probability values (percentages of 500 tree replications) are indicated at branch-points. 
maintained at a temperature of $37^{\circ} \mathrm{C}$. The solvent was $0.02 \mathrm{M} \mathrm{NH} \mathrm{NH}_{4} \mathrm{PO}_{4}(\mathrm{pH} 4.0)$ with $1.5 \%$ acetonitrile. Non-methylated $\lambda$-phage DNA (Sigma) was used as the calibration reference. DNA G $+\mathrm{C}$ contents of the strains were $40 \cdot 6-41 \cdot 5 \mathrm{~mol} \%$.

DNA-DNA hybridizations were performed between strains LMG 21734 ${ }^{\mathrm{T}}$, LMG 21735, LMG 14394 and LMG 14399 (DNA was prepared as described above). The microplate method was used, as described by Ezaki et al. (1989) and Goris et al. (1998), using a HTS7000 Bio Assay Reader (Perkin Elmer) for fluorescence measurements. Biotinylated DNA was hybridized with unlabelled ssDNA, which was bound non-covalently to microplate wells. Hybridizations were performed at $35^{\circ} \mathrm{C}$ in hybridization mixture $(2 \times$ SSC, $5 \times$ Denhardt's solution, $2.5 \%$ dextran sulphate, $50 \%$ formamide, $100 \mu \mathrm{g}$ denaturated salmon sperm DNA $\mathrm{ml}^{-1}, 1250 \mathrm{ng}$ biotinylated probe DNA $\mathrm{ml}^{-1}$ ). Hybridization levels of $87-100 \%$ were found; this indicates that the strains constitute a single species.

Growth tests were carried out as described by Švec et al. (2001). Lancefield antigens were detected by using a Streptococcal Grouping kit (Oxoid). Biochemical reactions were determined in a BBL CRYSTAL Gram-positive ID kit (Becton Dickinson), in API $50 \mathrm{CH}$ galleries under paraffin cover and in the API 20 STREP system (bioMérieux). The strains can be differentiated morphologically from other streptococci by their very small cell size. The strains all produce narrow zones of starch hydrolysis around growth patches on Columbia agar base, very similar to the zones that are seen with S. suis strains. Although the new taxon has biochemical features in common with its closest known relatives to date, S. ovis and S. entericus, several tests clearly differentiated the strains from these two species (Table 1). S. suis is probably the most likely source of confusion in phenotypic identification approaches, due to its highly variable biochemical activity; acid production from mannitol and $\beta$-gentiobiose could be used, as these reactions are rarely present in S. suis strains. A detailed description of the phenotypic characteristics of the novel species, for which we propose the name Streptococcus minor sp. nov., is given below.

Table 1. Characteristics that differentiate S. minor from its closest phylogenetic relatives

Species: 1, S. minor; 2, S. ovis; 3, S. entericus. Based on data from Collins et al. (2001), Vela et al. (2002) and the present study.

\begin{tabular}{|llll|}
\hline Characteristic & $\mathbf{1}$ & $\mathbf{2}$ & $\mathbf{3}$ \\
\hline Hydrolysis of arginine & + & + & - \\
Acid from: & & & \\
$\quad$ Rhamnose & - & + & - \\
Amygdalin & + & - & - \\
Mannitol & + & + & - \\
$\beta$-Gentiobiose & + & - & - \\
\hline
\end{tabular}

\section{Description of Streptococcus minor sp. nov.}

Streptococcus minor (mi'nor. L. masc. adj. minor smaller).

Cells are very small $(<1 \mu \mathrm{m}$ in diameter), Gram-positive, ovoid and arranged predominantly in small groups. Colonies on Columbia sheep blood agar are about $0.5 \mathrm{~mm}$ in diameter, unpigmented, regular, translucent and surrounded by narrow zones of $\alpha$-haemolysis. Growth is enhanced slightly by incubation in $5 \% \mathrm{CO}_{2}$ and is definitely better at $37^{\circ} \mathrm{C}$ than at $42^{\circ} \mathrm{C}$, and growth at $25^{\circ} \mathrm{C}$ is almost equal to growth at 30 or $37^{\circ} \mathrm{C}$. Strains show homogeneous growth in brain heart infusion broth (Oxoid). They grow on Edwards medium (Oxoid), but not on Slanetz and Bartley agar (Oxoid). On bile aesculin agar (Oxoid), blackening is observed. None of the strains reacts with Lancefield groups A, B, C, D, G or F antisera. All strains tested positive for leucine arylamidase (API), hydrolysis of L-valine-AMC (Crystal), L-phenylalanineAMC (Crystal), 4MU- $\alpha$-D-glucoside (Crystal), L-tryptophanAMC (Crystal), L-arginine-AMC (Crystal), L-isoleucine-AMC (Crystal) and aesculin (API, often delayed). In API $50 \mathrm{CH}$ tests, acid is produced from galactose, D-glucose, D-fructose, D-mannose, mannitol (often delayed), $N$-acetylglucosamine, salicin, cellobiose, maltose, lactose, sucrose, trehalose, glycogen and $\beta$-gentiobiose (often delayed). All strains tested negative for activity of hippurate (API), pyrrolidonyl arylamidase (API), $\beta$-glucuronidase (API), $\beta$-galactosidase (API) and alkaline phosphatase, and for acid production from glycerol, erythritol, DL-arabinose, ribose, DL-xylose, adonitol, methyl $\beta$-xyloside, L-sorbose, rhamnose, dulcitol, inositol, methyl $\alpha$-D-mannoside, methyl $\alpha$-glucoside, melibiose, melezitose, xylitol, D-turanose, D-lyxose, DL-fucose, DL-arabitol, gluconate and 2- and 5-ketogluconate. Results are strain-dependent for $\alpha$-galactosidase (often weak) and alkaline phosphatase activity (one of nine strains was positive), hydrolysis of $p$-nitrophenyl phosphate (Crystal) and acid production from sorbitol, amygdalin, arbutin, inulin, D-raffinose, starch and D-tagatose. DNA G+C content is $40 \cdot 6-41 \cdot 5 \mathrm{~mol} \%$.

The type strain is $\mathrm{ON} 59^{\mathrm{T}}\left(=\mathrm{LMG} 21734^{\mathrm{T}}=\mathrm{CCUG} 47487^{\mathrm{T}}\right)$, which was isolated from the tonsils of a dog. Habitat: tonsils and intestinal tract of dogs and tonsils of cats and cattle.

\section{Acknowledgements}

This research was supported by the Prime Minister's Services - Federal Office for Scientific, Technical and Cultural Affairs, Belgium. We thank A. Balcaen for determination of DNA G + C contents. The authors are very grateful to Jurgen De Craene for his excellent technical assistance.

\section{References}

Baele, M., Baele, P., Vaneechoutte, M., Storms, V., Butaye, P., Devriese, L. A., Verschraegen, G., Gillis, M. \& Haesebrouck, F. (2000). Application of tRNA intergenic spacer PCR for identification of Enterococcus species. J Clin Microbiol 38, 4201-4207.

Baele, M., Storms, V., Haesebrouck, F., Devriese, L. A., Gillis, M., Verschraegen, G., de Baere, T. \& Vaneechoutte, M. (2001). 
Application and evaluation of the interlaboratory reproducibility of tRNA intergenic length polymorphism analysis (tDNA-PCR) for identification of Streptococcus species. J Clin Microbiol 39, 1436-1442.

Baele, M., Vaneechoutte, M., Verhelst, R., Vancanneyt, M., Devriese, L. A. \& Haesebrouck, F. (2002). Identification of Lactobacillus species using tDNA-PCR. J Microbiol Methods 50, 263-271.

Coenye, T., Falsen, E., Vancanneyt, M., Hoste, B., Govan, J. R. W., Kersters, K. \& Vandamme, P. (1999). Classification of Alcaligenes faecalis-like isolates from the environment and human clinical samples as Ralstonia gilardii sp. nov. Int J Syst Bacteriol 49, 405-413.

Collins, M. D., Hutson, R. A., Hoyles, L., Falsen, E., Nikolaitchouk, N. \& Foster, G. (2001). Streptococcus ovis sp. nov., isolated from sheep. Int J Syst Evol Microbiol 51, 1147-1150.

Ezaki, T., Hashimoto, Y. \& Yabuuchi, E. (1989). Fluorometric deoxyribonucleic acid-deoxyribonucleic acid hybridization in microdilution wells as an alternative to membrane filter hybridization in which radioisotopes are used to determine genetic relatedness among bacterial strains. Int J Syst Bacteriol 39, 224-229.

Goris, J., Suzuki, K., De Vos, P., Nakase, T. \& Kersters, K. (1998). Evaluation of a microplate DNA-DNA hybridization method compared with the initial renaturation method. Can J Microbiol 44, 1148-1153.

Mesbah, M., Premachandran, U. \& Whitman, W. B. (1989). Precise measurement of the $\mathrm{G}+\mathrm{C}$ content of deoxyribonucleic acid by high-performance liquid chromatography. Int J Syst Bacteriol 39, 159-167.
Pitcher, D. G., Saunders, N. A. \& Owen, R. J. (1989). Rapid extraction of bacterial genomic DNA with guanidium thiocyanate. Lett Appl Microbiol 8, 151-156.

Pot, B. \& Janssens, D. (1993). The potential role of a culture collection for identification and maintenance of lactic acid bacteria. In Lactic Acid Bacteria: Proceedings of the First Lactic Acid Bacteria Computer Conference, pp. 81-87. Edited by E.-L. Foo, H. G. Griffin, R. Möllby \& C.-G. Hedèn. Norfolk, UK: Horizon.

Pot, B., Vandamme, P. \& Kersters, K. (1994). Analysis of electrophoretic whole-organism protein fingerprints. In Chemical Methods in Prokaryotic Systematics, pp. 493-521. Edited by M. Goodfellow \& A. G. O'Donnell. Chichester, UK: Wiley.

Stackebrandt, E. \& Goebel, B. M. (1994). Taxonomic note: a place for DNA-DNA reassociation and 16S rRNA sequence analysis in the present species definition in bacteriology. Int J Syst Bacteriol 44, 846-849.

Švec, P., Devriese, L. A., Sedláček, I., Baele, M., Vancanneyt, M., Haesebrouck, F., Swings, J. \& Doškař, J. (2001). Enterococcus haemoperoxidus sp. nov. and Enterococcus moraviensis sp. nov., isolated from water. Int J Syst Evol Microbiol 51, 1567-1574.

Vela, A. I., Fernández, E., Lawson, P. A., Latre, M. V., Falsen, E., Domínguez, L., Collins, M. D. \& Fernández-Garayzábal, J. F. (2002). Streptococcus entericus sp. nov., isolated from cattle intestine. Int J Syst Evol Microbiol 52, 665-669.

Welsh, J. \& McClelland, M. (1992). PCR-amplified length polymorphisms in tRNA intergenic spacers for categorizing staphylococci. Mol Microbiol 6, 1673-1680. 